\title{
Diversity and distribution of soil nematodes in Ngere tea catchment area of Murang'a county, Kenya
}

\author{
Tom Kosgei Kibet ${ }^{*}$, Johnson Kinyua ${ }^{1}$, Daniel Kariuki ${ }^{1}$, Edward George Mamati ${ }^{2}$ and \\ Justus Onguso ${ }^{3}$
}

\footnotetext{
${ }^{1}$ Department of Biochemistry, Jomo Kenyatta University of Agriculture and Technology P. O. BOX 62000-00200, Nairobi, Kenya.

${ }^{2}$ Department of Horticulture, Jomo Kenyatta University of Agriculture and Technology P. O. BOX 62000-00200, Nairobi, Kenya.

${ }^{3}$ Institute for Biotechnology Research, Jomo Kenyatta University of Agriculture and Technology P. O. BOX 62000-00200, Nairobi, Kenya.

Accepted 9 May, 2013
}

\begin{abstract}
A survey was conducted to determine the diversity and distribution of soil nematodes associated with tea in Ngere tea catchment area in Kenya. Soil samples were collected from six electoral zones of Ngere factory in Gatanga division Thika district, Murang'a County, Kenya. Nematodes were extracted and recovered from soil samples using a modified Baermann funnel method and identified under a light microscope based on their morphological characters. They were also classified according to their feeding habits. Ten genera belonging to, bacteriovores, fungivores, and omnivores were identified. Fungal feeding and parasitic nematodes were the most widely distributed trophic groups across the tea catchment area. Plant-parasitic nematodes recovered included Pratylenchus spp., Helicotylenchus spp., Rotylenchus spp., Aphelenchus spp., Rotylenchulus spp., and Xiphinema spp. Tylenchus spp was the most frequently occurring species in the soil $(60.47 \%)$ where the population was 429 followed by Pratylenchus spp with $55.81 \%$ frequency rating and a population of 404 while Aphelenchus spp had frequency rating of $48.84 \%$ and a population of 530 . Ditylenchus and Rotylenchus spp had the lowest frequency rating of 6.98 and $4.65 \%$, respectively, while Rotylenchus spp had the lowest population of 33. Six genera of plant parasitic nematodes were encountered in the collected soil samples. These plant parasitic nematodes were identified as Pratylenchus spp., Aphelenchus spp., Helicotylenchus spp., Tylenchus spp., Xiphinema spp and Duotylenchus spp. Pratylenchus spp. and Tylenchus spp. were the most frequently occurring species in the soil (50\%) with a population of 25 and 21, respectively, which was followed by Helicotylenchus spp., Aphelenchus spp., Xiphinema spp., and Duotylenchus spp. with $16.67 \%$ frequency rating and a population of 10, 10, 3 and 20, respectively. Pratylenchus spp had the highest nematode population of $28.09 \%$ and the lowest nematode population was Xiphinema spp., having a population of $3.37 \%$. The correlation between nematode population counts and total organic carbon content was not significant at $P \geq 0.05$.
\end{abstract}

Key words: Tea, frequency, nematode population, carbon content, Pratylenchus spp., Helicotylenchus spp., Rotylenchus spp., Aphelenchus spp., Rotylenchulus spp., and Xiphinema spp.

\section{INTRODUCTION}

Tea (Camellia sinensis (L.) O. Kuntze) plant is an important source of different beverages which are claimed to be the most widely consumed fluids after water. It is grown in many countries ranging from as far 
north as $49^{\circ} \mathrm{N}$, outer

Carpathians to as far as $30^{\circ} \mathrm{S}$; Natal, South Africa and from altitudes varying from sea level in Japan to $2700 \mathrm{~m}$ above mean sea level (amsl) in Olenguruone, Kenya and Gisovu, Rwanda. The plant is widely adaptable to geographical areas with large variations in climate and physical features which affect rates of growth, yields and quality (Owuor et al., 2010; Sarkar et al., 2010).

Nematodes are small worm-like organisms which are present in almost all agroecosystems where they interact directly and indirectly with plants and other microfauna, regulating decomposition and release of nutrients to the plants (Colman et al., 1984). Nematodes are ubiquitous and have diverse feeding habits and life strategies ranging from colonizers to persistors (Bongers, 1990; Yeates and Bongers, 1999). Due to their diversity in biological and particularly feeding habits, nematodes are an integral part of the food webs in soil ecosystems (Yeates et al., 1993). In almost every soil sample, nematodes from five trophic levels namely bacteriovores, fungivores, herbivores, predators and omnivores are usually represented (Freckman and Baldwin, 1990). Plant parasitic nematodes are the most intensively studied group because of their economic importance as biotic constraints to crop production. However, as the role of soil nematodes in regulating soil bacterial and fungal populations and thus cycling of major soil nutrients becomes clear (Yeates and Bongers, 1999). Consequently, overall focus is shifting from plant parasitic nematodes to the entire nematode community in the soil. The diversity of nematodes in agro-ecosystems and the total abundance of members of different trophic levels are largely controlled by the biophysical, chemical and hydrological conditions of the soil (Yeates and Bongers, 1999). This study focused on the identification of soil nematodes as well as their diversity in small holder tea growing farms in Ngere tea catchment area, Murang'a County, Kenya.

\section{MATERIALS AND METHODS}

Rhizosphere soils were sampled from Ngere tea catchment area where thirty seven farms, each selected in thirty seven tea buying centers, were considered in Ngere factory in Gatanga division Thika district, Murang'a county, Kenya. Soil sample (ca. $400 \mathrm{~g}$ ) was a composite of 3 to 10 random sub-samples, taken at least 8 to $10 \mathrm{~m}$ apart, from the surface to a depth of $45 \mathrm{~cm}$ of the four cardinal points of the rhizosphere of the tea bush. All sub-samples were mixed together and placed in a paper bag and then a polythene bag to prevent water loss and kept in a cooler (ca. $15^{\circ} \mathrm{C}$ ) during transit to the laboratory as suggested by Kaya and Stock (1997). The samples were thoroughly mixed and $20 \mathrm{~cm}^{3}$ of each soil samples was used for nematode extraction using modified Baermann funnel technique. Nematode numbers were counted, population of each genera was determined and identification to genus level was done under a compound microscope at a magnification of $\times 400$ to $\times 1000$ (Karuri et al., 2010).

Nematode genera were assigned to trophic groups (bacterial and fungal feeders, plant parasites, omnivores and predators) as described by Yeates et al. (1993). Taxonomic groups were also assigned to colonizer-persistor ( $\mathrm{cp}$ ) values according to Bongers (1990). Physical and chemical properties of soil were measured. Total organic carbon (C) was estimated through Walkley and Black method. Relationships between soil organic carbon content and nematode population were derived using correlation analysis. All statistical computations were performed using XLSTAT version 7.5 (Addin software, New York). The population densities of different nematode species in the samples were calculated using the formulae:

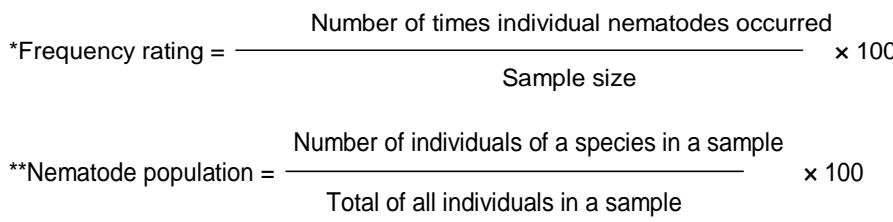

(Norton, 1978).

\section{RESULTS}

Ten genera of plant parasitic nematodes were encountered in rhizosphere soil samples collected from Ngere tea catchment area. In the soil, plant parasitic nematodes identified were Pratylenchus spp., Helicotylenchus spp., Rotylenchus spp., Aphelenchus spp., Rotylenchulus spp. and Xiphinema spp. Tylenchus spp. was the most frequently occurring species in the soil $(60.47 \%)$ where the population was $429 / 20 \mathrm{~cm}^{3}$ of soil which was followed by Pratylenchus spp with $55.81 \%$ frequency rating and a population of $404 / 20 \mathrm{~cm}^{3}$ of soil while Aphelenchus spp had frequency rating of $48.84 \%$ and a population of $530 / 20 \mathrm{~cm}^{3}$ of soil (Table 1 ). Ditylenchus and Rotylenchus spp had the lowest frequency rating of 6.98 and $4.65 \%$, respectively while Rotylenchus spp had the lowest population of $33 / 20 \mathrm{~cm}^{3}$ of soil (Table 1).

Six genera of plant parasitic nematodes were encountered in infected soil samples collected. In the soils with infected plants, plant parasitic nematodes identified were Pratylenchus spp., Aphelenchus spp., Helicotylenchus spp., Tylenchus spp., Xiphinema spp and Duotylenchus spp. Pratylenchus spp. and Tylenchus spp. were the most frequently occurring species in the soil $(50 \%)$ with a population of $25 / 20$ and $21 / 20 \mathrm{~cm}^{3}$ soil, respectively, which was followed by Helicotylenchus spp., Aphelenchus spp., Xiphinema spp., and Duotylenchus spp. with $16.67 \%$ frequency rating and a population of $10 / 20,10 / 20,3 / 20$ and $20 / 20 \mathrm{~cm}^{3}$ of soil, respectively. Pratylenchus spp had the highest nematode population of $28.09 \%$ and the lowest nematode population was Xiphinema spp., having a population of $3.37 \%$ (Table 2).

Two fungal genera (Aphelenchus and Cervidellus) were recorded. Only one genus (Dorylaimus) of omnivore nematodes and (Cervidillus) of bacteriovores were observed. Fungal feeding and parasitic nematodes were the most abundant trophic groups (Table 3). The correlation between nematode population and organic carbon content was not significant at $P \geq 0.05$. 
Table 1. Nematodes extracted from soils around the roots of Tea bushes in Ngere.

\begin{tabular}{lccccc}
\hline $\begin{array}{l}\text { Nematode } \\
\text { genera }\end{array}$ & $\begin{array}{c}\text { C-P } \\
\text { values }\end{array}$ & $\begin{array}{c}\text { Population/20 } \\
\text { of soil }\end{array}$ & $\begin{array}{c}\text { Frequency of } \\
\text { occurrence }\end{array}$ & $\begin{array}{c}\text { Frequency } \\
\text { rating }\end{array}$ & $\begin{array}{c}\text { Nematode } \\
\text { population }\end{array}$ \\
\hline Aphelenchus & 2 & 530 & 21 & 48.8 & 25.9 \\
Cervidellus & 2 & 140 & 12 & 27.9 & 6.8 \\
Ditylenchus & 2 & 39 & 3 & 7.0 & 1.9 \\
Dorylaimus & 4 & 126 & 5 & 11.6 & 6.2 \\
Doutylenchus & 2 & 77 & 6 & 14.0 & 3.8 \\
Helicotylenchus & 3 & 127 & 6 & 14.0 & 6.2 \\
Pratylenchus & 3 & 404 & 24 & 55.8 & 19.8 \\
Rotylenchus & 3 & 33 & 2 & 4.7 & 1.6 \\
Tylenchus & 2 & 429 & 10 & 60.5 & 21.1 \\
Xiphinema & 5 & 139 & 23.3 & 6.8 \\
\hline
\end{tabular}

${ }^{*} \mathrm{n} / \mathrm{N} \times 100\left(\mathrm{n}=\right.$ number of times individual nematodes occurred and $\mathrm{N}=$ Sample size $(43) .{ }^{* *} \mathrm{In} / \mathrm{TN} \times 100$ (In = Individual nematode in all the samples and $\mathrm{TN}=$ Total Population of all the nematodes extracted in all the samples).

Table 2. Nematodes extracted from infected soils around the roots of tea bushes.

\begin{tabular}{lcccc}
\hline Nematode genera & $\begin{array}{c}\text { Population } / \mathbf{2 0} \mathbf{~ c m}^{\mathbf{3}} \\
\text { of soil }\end{array}$ & $\begin{array}{c}\text { Frequency of } \\
\text { occurrence }\end{array}$ & $\begin{array}{c}\text { Frequency rating } \\
\text { (\%) }\end{array}$ & $\begin{array}{c}\text { Nematode population }^{\star \star} \\
\text { (\%) }\end{array}$ \\
\hline Pratylenchus & 25 & 3 & 50 & 28.1 \\
Tylenchus & 21 & 3 & 50 & 23.6 \\
Helicotylenchus & 10 & 1 & 16.7 & 11.2 \\
Aphelenchus & 10 & 1 & 16.7 & 11.2 \\
Xiphinema & 3 & 1 & 16.7 & 3.4 \\
Duotylenchus & 20 & 1 & 16.7 & 22.5 \\
\hline
\end{tabular}

${ }^{*} \mathrm{n} / \mathrm{N} \times 100$ ( $\mathrm{n}=$ number of times individual nematodes occurred and $\mathrm{N}=$ Sample size $(6) .{ }^{* *} \mathrm{In} / \mathrm{TN} \times 100$ (In $=$ Individual nematode in all the samples and $\mathrm{TN}=$ Total Population of all the nematodes extracted in all the samples).

Table 3. Extracted nematodes according to their trophic group.

\begin{tabular}{llcl}
\hline Family & Genera & C-P Values & Trophic group \\
\hline Anguinidae & Ditylenchus & 2 & ${ }^{\mathrm{d}} \mathrm{FF}$ \\
Pratylenchidae & Pratylenchus & 3 & ${ }^{\mathrm{a}} \mathrm{PF}$ \\
Tylenchidae & Tylenchus & 2 & ${ }^{\mathrm{a}} \mathrm{PF}$ \\
Longidoridae & Xiphinema & 5 & ${ }^{\mathrm{a}} \mathrm{PF}$ \\
Aphelenchidae & Aphelenchus & 2 & ${ }^{\mathrm{d}} \mathrm{FF}$ \\
Cephalobidae & Cervidellus & 2 & ${ }^{\mathrm{b}} \mathrm{BF}$ \\
Tylenchidae & Doutylenchus & 2 & ${ }^{\mathrm{a}} \mathrm{PF}$ \\
Dorylaimidae & Dorylaimus & 4 & ${ }^{\mathrm{C}} \mathrm{OM}$ \\
Hoplolaimidae & Rotylenchus & 3 & ${ }^{\mathrm{a}} \mathrm{PF}$ \\
Hoplolaimidae & Helicotylenchus & 3 & ${ }^{\mathrm{P} F}$ \\
\hline
\end{tabular}

C-P: Colonizer-persister scale 1-5 where $\mathrm{cp} 1$ are colonizers characterized by short generation time and cp 5 are persisters characterized by long generation time (Bongers, 1990). ${ }^{\mathrm{a} P} \mathrm{Plant}$ feeders ${ }^{\mathrm{b}}$ Bacteriovores ${ }^{\mathrm{C}}$ Omnivores.

\section{DISCUSSION}

Nematodes in an agro-ecosystem are potential bioindicators due to their diversity and their relationships to soil processes (Yeates and Bongers, 1999). The nematode community structure can be used to assess changes in soil since these organisms respond rapidly to new resources (Bongers and Bongers, 1998). This study has demonstrated nematodes of the genera Aphelenchus spp., and Pratylenchus spp., are wide spread in the tea fields of Ngere catchment area. These findings are in agreement with the previous studies elsewhere (Kimenju 
Table 4. Correlation between nematode population and organic carbon content.

\begin{tabular}{lcc}
\hline \multirow{2}{*}{ Variable } & \multicolumn{2}{c}{$\mathrm{p}$-values } \\
\cline { 2 - 3 } & Nematode population & Organic carbon content \\
\hline Nematode population & 0 & 0.173 \\
Organic carbon content & 0.173 & 0 \\
\hline
\end{tabular}

Values in bold are different from 0 with a significance level alpha $=0.05$.

et al., 2009). Large numbers of fungal feeders were identified (Tables 1 and 3 ) and this could be an indication of decomposition of substrates with high $\mathrm{C}: \mathrm{N}$ ratios by fungi. The high abundance of fungal feeding nematodes could also be attributed to colonization of tea roots by large numbers of fungi. Similar findings have been observed by Feng et al. (2003) and Koenning and Barker (2004).

The condition of soils in Ngere tea catchment area can be improved by enhancing nutrient availability and providing habitat for beneficial soil organisms. Maintenance of large populations of bacterial-feeding and fungal feeding nematodes with practices that promote $\mathrm{N}$ mineralization may enhance crop productivity, but a surplus of mineral $\mathrm{N}$ is not desirable from the environmental point of view because of an increased risk of nitrate leaching (Neher, 1999). Cultural practices like tillage or cultivation may reduce the complexity of the soil food web. Thus, a decrease in the frequency and intensity of tillage may promote the conservation of predatory nematodes and contribute to improved farming system performance.

\section{Conclusion}

The study has demonstrated that Ngere tea catchment area harbours soil nematode species, 10 genera were isolated, characterized and identified. The findings also showed that the tea soils in Ngere tea catchment area had a high occurrence of fungal feeding nematodes.

\section{ACKNOWLEDGEMENTS}

Authors are deeply indebted to the Department of Biochemisty particularly Dr. Johnson Kinyua for the supervisory work and assistance that he accorded me. Also thanks to the Research, Production and Extension Division of Jomo Kenyatta University of Agriculture and Technology for funding the project.

\section{REFERENCES}

Bongers T (1990). The maturity index: An ecological measure of environmental disturbance based on nematode species composition. Oecology 83:14-19.
Bongers T, Bongers M (1998). Functional diversity of nematodes. Appl. Soil Ecol. 10:239-251.

Feng Y, Motta AC, Reeves DW, Burmester $\mathrm{CH}$, Santen van E, Osborne JA (2003). Soil microbial communities under conventionaltill and notill continous cotton systems Soil Biol. Biochem. 35:16931703.

Freckman DW, Baldwin JG (1990). Nematoda. In: "Soil Biology Guide". D.L. Dindal (ed.), John Wiley \& Sons, Inc., New York. Pp. 155-200.

Karuri HW, Amata R, Amugune N, Waturu C, Lovei G (2010). Occurrence and distribution of soil nematodes in cotton (Gossypium hirsutum L.) production areas of Kenya. Afri. J. Agric. Res. 5:14.

Kaya HK, Stock P (1997).Techniques in insect nematology.In: Lawrence, A.L. (Ed.). Manual of techniques in insect pathology. San Diego, CA, USA, Academic Press, pp. 282-324.

Kimenju JW, Karanja NK, Mutua GK, Rimberia BM, Wachira PM (2009). Nematode community structure as influenced by land use and intensity of cultivation. Trop. Subtrop. Agroecosystems 11:353-360.

Koenning SR, Barker KR (2004). Influence of litter applications on nematode communites in cotton agroecosystems. J. Nematol. 36:524-533.

Neher DA (1999). Soil community composition and ecosystem processes: Comparing agricultural systems with natural ecosystems. Agroforest. Syst. 45:159-185.

Norton DC (1978). Ecology of plant - parasitic nematodes. Wiley, New York.

Owuor PO, Wachira FN, Ng'etich WK (2010). Influence of region of production on relativeclonal plain tea quality parameters in Kenya. Food Chem. 119:1168-1174.

Sarkar S, Seenivasan S, Asir RPS (2010). Biodegradation of propargite by Pseudomonas putida, isolated from tea rhizosphere. J. Hazar. Mater. 174:295-298.

Yeates GW, Bongers T (1999). Nematode diversity in agroecosystems. Agric. Ecosyst. Environ. 74:113-135.

Yeates GW, Bongers T, De Goede RG, Freckman DW, Georgieva S (1993). Feeding habits in soil nematode families and genera--an outline for soil ecologists. J. Nematol. 25:315-331. 